\title{
İş-Aile Çatışmasının İşten Ayrılma Niyeti Üzerine Etkisini Belirlemeye Yönelik Turizm Sektöründe Bir Araştırma: Edremit Körfezi Örneği
}

\author{
Ergün Kara \\ Osmaniye Korkut Ata Üniversitesi
}

\begin{abstract}
Öz
İnsanlar doğal olarak yaşamlarının büyük bir bölümünü, işleri ve aileleri arasında bir denge sağlayarak geçirmektedirler. Ancak günümüzde bireylerin giderek artan ihtiyaç ve istekleri için daha çok çalışmaya başlamasıyla birlikte iş ve aile için üstlenilmiş olan roller arasında bir dengesizlik ortaya çıkmaktadır. Roller arasında ortaya çıkan bu taşmalar nedeniyle meydana gelen iş-aile çatışmaları, çalışanları çeşitli konulardan etkilemekte olup, söz konusu etkilerden biriside çalışanın işten ayrılma niyeti üzerinedir. İșten ayrılma niyeti, çalışanın işini bırakması ile ilgili düşüncesini ifade etmektedir. Çalışmada iş-aile çatışması ile işten ayrılma niyeti arasındaki ilişkinin boyutu ve yönü tespit edilerek, çözümüne ilişkin öneriler getirilmesi amaçlanmıştır. Bu amaç doğrultusunda çalışma, Balıkesir ili Edremit İlçesi'nde bulunan 4 ve 5 yıldızlı konaklama işletmeleri ile seyahat acentalarında görev yapan 200 personel araştırmanın evreni olarak belirlenmiştir. Örneklemi ise Edremit İlçesindeki konaklama işletmeleri ve seyahat acentelerinde görev yapan 120 personel oluşturmaktadır. Araştırmada, Carlson vd. (2000) tarafindan geliştirilen iş-aile çatışması ölçeği ile Reychav ve Weisberg'den (2009) tarafindan oluşturulan işten ayrılma niyeti ölçeği kullanılmıştır. Yapılan araştırmayla çalışanların yaşadığı iş-aile çatışmalarının, işten ayrılma niyeti üzerindeki etkisi incelenmiş ve turizm sektörü açısından işaile çatışması ile işten ayrılma niyeti arasında pozitif yönde ilişki olduğu saptanmıştır.
\end{abstract}

Anahtar Kelimeler: İş-Aile Çatışması, İşten Ayrılma Niyeti, Turizm Sektörü, Çalışan, Edremit 


\title{
A Research in Tourism Sector Towards Determining the Influence of the Conflict of Work-Family on the Intention of Quitting the Job: Edremit Bay Example
}

\author{
Ergün KARA \\ Osmaniye Korkut Ata University
}

\begin{abstract}
People spend the most of their natural lives trying to provide a balance between their jobs and families. But together with the individuals' working hard and a lot for the increasing needs and wishes of themselves, imbalance emerges between the roles undertaken for family and the job. Because of the conflicts emerged between the roles, the job-family conflicts influence the workers on several issues and one of the mentioned influences is on the intention of the worker's quitting the job. The intention to leave the job refers to the idea of the employee to quit his / her job. In this study, it was aimed to determine the size and direction of the relationship between workfamily conflict and intention to quit, and to propose suggestions for its solution. For this purpose, 4 and 5 star accommodation establishments in Edremit District of Ballkesir province and 200 personnel working in travel agencies were determined as the universe of the research. The sample consisted of 120 personnel working in accommodation establishments and travel agencies in Edremit District. In the study, Carlson et al. The work-family conflict scale developed by (2000) and the severance intention scale, created by Reychav and Weisberg (2009), were used. By this research, the influence of the job-family conflicts workers undergo and the influence on their intention of quitting the job has been studied and a positive relationship has been determined between the intention of quitting the job and the job-family conflict in terms of tourism sector
\end{abstract}

Keywords: Job-Family Conflict, Intention of Quitting the Job,Tourism Sector, Working, Edremit 


\section{Giriş}

Kişilerin çalışma ve aile yaşantıları arasında sağlıklı, verimli ve etkili bir denge kurması sadece kendileri için değil, aynı zamanda aile geleceğinin ve toplumun sosyal yapısının bozulmaması açısından oldukça önemlidir. Çalışılan örgütün yapısı, örgüt kültürü, kariyer hedefi, faaliyet gösterilen alan, kişinin evli veya bekâr olması, çocuk sayısı, eşinin çalışıp çalışmadı̆̆ 1 gibi etkenler iş-aile çatışması üzerinde doğrudan etkili olan durumlardır. Çatışmalar çalışanların aile hayatında ciddi sorunlara yol açabileceği gibi, çalışanın iş doyumu, örgütsel bağlılığı, performansı, yaratıcılığg üzerinde de olumsuz etkiye sahip olabilir. Dolayısıyla, iş-aile çatışmasının doğrudan etkilediği konulardan birisi de çalışanın işten ayrılma niyeti üzerinedir.

Rusbelt ve arkadaşları tarafından (1988), işten ayrılma niyetini konusunda yapılan çalışma sonucunda işten ayrılma niyeti; çalışanların çeşitli sebeplere bağlı olarak iş koşullarından tatminsizlik yaşamaları durumunda ortaya çıkan çalışan ve işletme açısından yıpratıcı eylem olarak tanımlanmıştır. İşten ayrılma niyeti, çalışanın sadece fikir olarak fiiliyata dönüşmemiş örgütü bırakma düşüncesi olarak tanımlanmaktadır (Şahin, 2011, s. 2).

Yapılan çalışmayla iş-aile çatışmasının, işten ayrılma niyeti üzerindeki etkisi nedenleriyle birlikte ortaya konulmuş ve sonuçları incelenmiştir. Araştırmada örnek kütle olarak belirlenen Edremit Körfezi'nde turizm sektöründe çalışan personel üzerinden iş-aile çatışmalarının işten ayrılma niyetlerini ne derece etkilediği belirlenmeye çalışılmıştır. Çalışmanın birinci ve ikinci kısmında iş aile çatışması ve işten ayrılma niyeti kavramsal olarak incelenmiş, üçüncü kısımda iki ifade arasındaki ilişki incelenerek oluşturulan hipotez test edilmiş ve çalışmanın son kısmında ise ortaya çıkan veriler değerlendirilmiştir.

\section{İş-Aile Çatışması}

Kişiler yaşamları boyunca hemen hemen bütün zamanlarını sahip oldukları rollerin gereğini yerine getirme çabası içerisinde geçirmektedirler. Rollerin, kişi üzerindeki yoğunluğu veya baskısı kişide çatışma yaşanmasına neden olabilmektedir. Bu tür bir çatışmada iş yaşamında üstlenilen 
rolün bir gereği olarak yapılması gerekenler ile ailede üstlenilen rol arasinda yaşanacak uyumsuzluğun artması sonucunda kişi üzerindeki gerilim artmakta ve iş-aile yaşam dengesi bozulmaktadır (Greenhaus ve Beutell, 1985, s. 76-88).

Genel anlamda iş-aile çatışması, kişinin aile yaşamında ve iş yaşamında gerçekleştirmek zorunda olduğu rollerden birisinin diğerine daha baskın olması veya engellemesi sonucu ortaya çıkmaktadır. Bir başka ifade ile iş-aile çatışması, iş veya aile yaşamındaki rollerin bir arada gerçekleştirilememesi durumudur. Üstlenilen rollerin arasında bir uyumsuzluk olması iş-aile çatışmasındaki şiddeti de buna bağlı olarak arttırmaktadır. Kişilerin sahip oldukları rollerden birisine olan bağlılığı arttıkça o role ayrılan zamanın artması diğer rolün beklentilerini yerine getirmeyi zorlaştırmaktadır (Frone ve Rice, 1987, s. 145-167).

Duxbury ve Higgins (1998), çalışmalarında iş-aile çatışmasının kişisel ve örgütsel açıdan sonuçlarının bulunduğuna dikkat çekmişlerdir. İş-aile çatışması kişi üzerinde ciddi baskılar oluşturabilir. Bu durumun ailede üstlenilen role yansıması genellikle psikolojik olarak karşımıza çıkmaktadır ve özellikle çocuklu ailelerde büyük sorunlara neden olabilmektedir. İş yaşamındaki etkileri ise kişinin iş tatmininin yok olması ve işe karşı olan memnuniyetsizliğinin artması, işten ayrılma niyeti üzerinde ciddi etki yapması ve çalışmada verimsizlik olarak kendisini göstermektedir (Taslak, 2007, s. 67-73).

\section{İş-Aile Çatışmasında Etkili Olan Faktörler}

Çatışmalarda genellikle bireysel özellikler ön plana çıkmakta olup, bu konudaki araştırmaların büyük çoğunluğu iş-aile çatışması yaşanmasında kişilik özellikleri ve cinsiyetin diğer etkenlerden daha fazla etkili olduğunu ortaya koymuştur. Erkek ve kadın çalışanların kişilikleri, yaşları, medeni durumları gibi etkenler, her bir cinsiyet üzerinde ayrı ayrı etkiye sahiptir (Greenhaus ve Beutell, 1985, s. 76-88).

- Kişisel Faktörler: İş-aile çatışmasında etkili olan kişisel faktörler temelde cinsiyete ve kişiliğe bağlı olarak yaşanan çatışmalar olarak ifade edilebilir. İş-aile çatışması konusundaki araştırmalar, cinsiyetin çatışma yaşanmasındaki en önemli etkenlerden birisi olduğunu gös- 
termektedir. Genel olarak kadınların erkeklerden daha düşük ücret almaları, kariyer fırsatlarından daha az yararlanmaları ve bazı işletmelerde erkek egemenliğine rağmen kadınların iş tatminin daha yüksek olduğu görülmektedir (Chusmir ve Parker, 2001, s. 87-99).

- İş İle İlgili Faktörler: Teknolojik gelişmelerin ve değişmelerin bir sonucu olarak iş hayatındaki çalışma şartlarında değişikliler meydana gelmiştir. Bu durumun bir sonucu olarak işin yapısı, çalışma şartları ve iş için gerekli olan nitelikler de doğrudan etkilenmiş ve çeşitli değiş̧iklikler olmuştur. Artık sadece iş hayatında erkekler değil kadınlar da yer almaya başlamış, çekirdek ailedeki rollerde ciddi değişimler meydana gelmeye başlamıştır. Hem erkeklerin hem de kadınların iş ve aile yaşamındaki rollerini en iyi şekilde yerine getirmek istemeleri çatışma yaşanılmasına neden olmaktadır (Doğrul ve Tekeli, 2010, s. 11-16).

- Aile İle İlgili Faktörler: Aile faktörünün iş-aile çatışması üzerindeki etkisinde kişilerin aile hayatında sahip oldukları rolün gereği olan sorumlulukların iş yaşantılarındaki rollerini olumsuz etkilemesi sonucu gelişmektedir. Buradaki esas olan ailede yaşanılan durumların iş yaşantısını olumsuz etkilemesidir. Çalışanların ailede yaşadıkları bireysel sorunlar, çocukların problemleri, eşler arasındaki uyumsuzluk, ailede bakıma muhtaç yaşlılar bulunması vb. gibi durumlar çatışma ortamı yaşanmasına neden olmaktadır (Doruk, 2009, s. 69-99).

\section{İş-Aile Çatışması Konusundaki Yaklaşımlar}

Ailede üstlenilen rolün ve iş hayatında üstlenilen rolün birbirlerini etkilemedikleri, her iki rol alanının da birbirlerine müdahalesi olmadığı sadece kişisel özelliklere bağlı olarak çatışmaların çıtığı yönünde varsayımlar bulunmasına rağmen, iş-aile çatışması alanında yapılan çalışmalar ışığında meydana çıkmış aşağıda belirtilen beş temel kuramın oluştuğu söylenebilir (Efeoğlu, 2006):

- Akılcı Bakış Açısı Kuramı: Bu kurama göre iki rol arasında çatışma yaşanmasının asıl nedeni, iş ve aile yaşamındaki yoğunluk, zaman yetersizliği ve roller arasındaki uyumsuzluklara bağlı olarak meydana gelmektedir. Günümüz koşullarında daha fazla para ve 
statü kazanmak amacıyla ailede geçirilecek zamanlar iş alanına kaymakta, roller arasında denge bozulmakta, sonuç olarak da şiddetli çatışmalar ortaya çıkmaktadır (Efeoğlu, 2006).

- Telafi Kuramı: “Telafi kuramı" iş hayatı ve özel hayat arasında zıt yönlü bir ilişkinin olduğu belirten bir teoridir. Bireyler yaşamlarını daha düzenli hale getirmek ve yapacakları eylemlerde tatmin seviyelerini yükseltmek amacıyla, gerek iş yaşamında gerekse aile yaşantısinda diğerinde bulunmayan eksiklikleri telafi etme yoluna giderler (Adams, King ve Daniel, 1996, s. 403-411).

- Katkı Kuramı: Duxbury ve Higgins, Cookee ve Roussea'nın çalışmalar ile benzeri diğer çalışmalar bize göstermektedir ki, katkı kuramının temelinde kişinin özel ve çalışma hayatına ait temel rollerin karşılıklı olarak birbirleri üzerine yapmış oldukları etkinin, çalışan bireyin genel yaşam kalitesini doğrudan etkilediği varsayımı bulunmaktadır (Efeoğlu, 2006).

- Taşma Kuramı: Taşma kuramı, iş veya aile hayatındaki rollerden herhangi birindeortaya çıkan noksanlıkları gidermek amacıyla bir role ötekinden daha fazla ağırlık verilmesi sonucu ortaya çıkan çatışmadır (Clark, 2000, s. 770).

- Çatışma Kuramı: Çatışma kuramına göre iş ve aile hayatında kişinin üstlenmiş olduğu roller devamlı olarak çatışma halindedir ve kişiyi fizyolojik ve psikolojik olarak etkilediği için sürekli olarak yaşanmaktadır. Rollerden birinde sağlanacak tatmin ya da başarı için diğer alandaki rolde fedakârlığı gerektirmekte olup, bu durumun bir sonucu olarak da roller arasında uyumsuzluk bulunduğu durumlarda çatışma ortaya çıkmaktadır (Zedeck ve Mosier, 1990, s. 240-251).

\section{İşten Ayrılma Niyeti}

Örgütlerde işten ayrılma niyeti, personelin çalışma şartlarında veya kişisel problemlerine bağlı olarak ortaya çıkan tatminsizlikler nedeniyle oluşan ve fiiliyata geçmemiş sadece çalışanın ayrılma planını içeren düşüncelerdir. Çalışanların, örgüt kültürüne bağlılığ1 yüksek iş tatmininin sağlanmasına ve dolayısıyla işten ayrılma niyetinin de düşük seviyede olduğu gözlemlenmiştir. Ancak kişinin işten ayrılma niyetini doğrudan veya dolaylı olarak etkileyen birçok konu bulunmakta olup, işletmelerin 
aleyhine bir durum olarak ayrılma niyeti kişinin kendi kararları doğrultusunda şekillenmektedir (Lambert, Hogan ve Barton, 2001, s. 233-250).

İşten ayrılma niyeti gerçek işten ayrılmadan farklıdır, öyle ki işten ayrılma niyeti iş görenlerin iş yerinde kalmak ya da istifa etmek için kendini değerlendirme niyetleridir. İşten ayrılma niyetinin, gerçek işten ayrılmaya yol açtığı tespit edilmiştir. İşten ayrılma bir örgütte giderlerle sonuçlanabilir ki bu organizasyonların giderleri yeni çalışanları seçme ve onların eğitimi ile ilgilidir (Örücü ve Özafşarlığlu, 2013, s. 335).

Yeni personelin eğitimi ile yeni personel ve eski personelin uyumundan kaynaklanacak olan maliyetleri yükleyecektir. Tüm bu olumsuz durumlardan kaçınmak isteyen işletmeler çalışanları işletmede tutacak etkin insan kaynakları yönetimi politikalarını uygulamak zorundadır. İşletmelere maliyetler yükleyen çalışanın işten ayrılma niyeti üzerinde etkisi olan bireysel ve örgütsel faktörler bulunmaktadır. Yapılan çalışmalar incelendiğinde, iş-aile çatışması, iş tatmini, örgütsel bağlılık, örgütsel adalet algısı, tükenmişlik, örgütsel vatandaşlık ve aşırı iş yükü, örgütsel özdeşleşme, lider-üye etkileşimi, algılanan yeni iş fırsatı ile üstlerden ve çalışma arkadaşlarından alınan sosyal destek değişkenleri ile çalışanların işten ayrılma niyeti üzerinde bir etkisi olduğu ortaya konmuştur (Yenihan ve Diğ. 2014, s. 38-49).

İşten ayrılma eğilimini belirleyen kişisel faktörlerin başında kişilik özellikleri gelmektedir. Buna göre, düşük düzeyde yumuşak başlılık ve yüksek düzeyde deneyime açıklık ve duygusal istikrarsılı̆ı̆ın işten ayrılma niyeti üzerinde olumlu etkisinin olduğu belirtilmektedir (Zimmerman, 2008). Ayrıca, yumuşak başlı kişilerin, nazik, kibar, fedakâr, ince ruhlu, uzlaşmacı, çözüm odaklı ve diğerleriyle tatmin edici ve olumlu ilişkilerde bulunma eğilimlerinden dolayı işlerinden ayrılma eğilimlerine sahip olmadıkları vurgulanmaktadır (Barrick, Stewart ve Piotrowski, 2002; Goldberg, 1990; Organ ve Lingl, 1995; Zimmerman, 2008).

Kişilik özelliklerinin yanında işgörenin demografik özellikleri (cinsiyet, medeni durum, iş tecrübesi, yaş vb.), başka bir işe duyulan sempati, evlenme, emeklilik, sağlık durumu, eğitim ihtiyacı, iş ile ilgili beklentilerin gerçekleşmemesi gibi faktörler de kişisel faktörler içinde yer almaktadır (Aslan ve Etyemez, 2015, s. 482). 


\section{İş-Aile Çatışması ve İşten Ayrılma Niyeti Arasındaki İlişki}

İşten ayrılma niyeti çalışanın işini bırakması ile ilgili düşüncesini ifade etmektedir. Bir çalışanın işine karşı geliştirmiş olduğu düşüncelerde bağlı olduğu liderinin önemli ölçüde etkileri bulunmaktadır. Literatürde de bu ilişkiyi doğrulayan çok sayıda araştırmalara rastlamak mümkündür. Yapılan çalışmalar incelendiğinde, iş-aile çatışması (Babajide ve Diğ., 2010; Noor ve Maad, 2008) ile çalışanların işten ayrılma niyeti üzerinde ilişki olduğu ortaya konmuştur (Yenihan ve Diğ. 2014, s. 38 -49).

Bütün hizmet sektörlerinde olduğu gibi turizm sektöründe de en önemli unsurun müşteri memnuniyeti olduğu düşünüldüğünde, iş-aile çatışması ve ortaya çıkardığı sonuçların önemi ortaya çıkmaktadır. Bu konuda yapılan araştırma sonuçlarına göre; iş- aile çatışması işten ayrılma niyetini artırıcı yönde etkilemektedir (Frone ve Dĭ̆ , 1997; Kossek ve Özeki, 1999; Carlson ve Diğ., 2000; Powell ve Greenhaus, 2006). Buna göre, işve aile rolleri arasında denge kuramama sorunu çalışanda yabancılaşma sorununa neden olmakta, dolayısıyla işten ayrılma niyeti artmaktadır (Çarıkçı ve Çelikkol, 2009, s. 153).

\section{Araştırmanın Yöntemi}

\section{Araştırmanın Amacı ve Hipotezleri}

Çalışmada iş-aile çatışması ile işten ayrılma niyeti arasındaki ilişkinin boyutu ve yönü tespit edilerek, çözümüne ilişkin öneriler getirilmesi amaçlanmıştır. Çalışmanın amacı doğrultusunda ve literatür taraması sonuçlarına bakılarak araştırmanın hipotezi aşağıdaki şekilde belirlenmiştir.

Hipotez-1: İş-aile çatışması ile işten ayrılma niyeti arasında pozitif yönlü bir ilişki vardır.

\section{Araştırmanın Ölçekleri}

Araştırma için veri toplama yöntemi olarak anket uygulaması yapılmıştır. Çalışma, Balıkesir ili Edremit İlçesinde bulunan 4 ve 5 yıldızlı konaklama işletmeleri ile seyahat acentalarında görev yapan 200 personel araştırmanın evreni olarak belirlenmiştir. Sezonluk çalışan personel üzerinde gerçekleştirilecek anket çalışmasının sağlıklı sonuç vermeyeceği düşünülerek, araştırma için özellikle kış sezonunda da devamlı görev yapan 
personel tercih edilmiştir. Bu durum ankete katılımı oranını etkilemiş olup, geri dönüş sağlanan anketlerin arasında sağlıklı cevap verilen 120 anket araştırmaya konu edilmiştir.

Hazırlanan anket formunun birinci kısminda katılımciya ait demografik özellikler, ikinci kısmında yer alan 1-13 arası Carlson vd. (2000) tarafından geliştirilen ve güvenilirlik katsayısı 0,92 olan iş-aile çatışması ölçeği, 14-19 arası ifadeler ise Reychav ve Weisberg'den (2009) tarafından kullanılan, güvenilirlik katsayısı 0,93 olan ve araştırma için iş- aile çatışmasına yönelik olarak geliştirilen işten ayrılma niyeti ölçeği bulunmaktadır. Ankette format olarak 5'li likert tipi ölçek (1= Kesinlikle Katılmıyorum, 2= Katılmıyorum, 3= Kararsızım, 4= Katılıyorum, 5= Kesinlikle Kat1lıyorum) kullanılmıştır.

\section{Bulgular}

Çalışmanın bu kısmında, toplanan veriler üzerinde yapılan istatistiksel analizler değerlendirilmiş ve elde edilen bulgular aşağıda açıklanmaya çalışılmıştır.

Tablo 1: Katılımcılara İlişkin Bilgiler

\begin{tabular}{|c|c|c|c|c|c|}
\hline Cinsiyet & $\mathbf{N}$ & $(\%)^{*}$ & Görev Süresi & $\mathbf{N}$ & $(\%)^{*}$ \\
\hline Bayan & 46 & 38 & 1 Yildan az & 23 & 19 \\
\hline Erkek & 74 & 62 & 1- $5 Y_{11}$ & 85 & 71 \\
\hline Toplam & 120 & 100 & 5- $10 \mathrm{Y}_{1}$ & 9 & 8 \\
\hline Yaş & $\mathbf{N}$ & $(\%)^{*}$ & 10 Yildan Fazla & 3 & 2 \\
\hline $20-30$ & 36 & 30 & Toplam & 120 & 100 \\
\hline $26-30$ & 62 & 52 & & & \\
\hline 40 ve üzeri & 22 & 18 & Eğitim Düzeyi & $\mathbf{N}$ & $(\%)^{*}$ \\
\hline Toplam & 120 & 100 & İlköğretim & -- & -- \\
\hline Medeni Durum & $\mathbf{N}$ & $(\%)^{*}$ & Lise & 14 & 14 \\
\hline Evli & 88 & 73 & Ön Lisans & 71 & 59 \\
\hline \multirow[t]{2}{*}{ Bekar } & 32 & 27 & Lisans & 30 & 25 \\
\hline & 120 & 100 & Lisansüstü & 2 & 2 \\
\hline Ünvan & $\mathbf{N}$ & $(\%)^{*}$ & Toplam & 120 & 100 \\
\hline Yönetici & 31 & 26 & & & \\
\hline Çalışan & 89 & 74 & & & \\
\hline Toplam & 120 & 100 & & & \\
\hline
\end{tabular}

* Yüzdeler yaklaşık olarak yuvarlanmıştır. 
Tablo 1'e göre; araştırmaya katılanların \%62'si erkek, \%38'i ise kadınlardan oluşmaktadır. Bu durum turizmde sezon dişı olduğu düşünüldügünde oransal olarak kadın çalışan sayısında sezona göre önemli bir düşüş yaşanmadığını göstermektedir. Katılımcıların büyük çoğunluğu (\%82) 20-40 yaşa aralığında olup, yine bu çoğunluğunda \%73'ü evli çal1şanlardan oluşmaktadır. Ankete katılan yöneticilerin sayısı 31 (\%26) çalışanların sayısı ise $89^{\prime}$ dur(\%74). Ayrıca eğitim seviyesi olarak çalışanların $\% 59$ 'u ön lisans mezunu olup, turizm işletmelerinde görev yapma süresinin 1-5 yıl aralığında (\%71) kümelendiği ve çok az çalışanın (\%10) 5 yıl üzerinde aynı işletmede görev yaptığı görülmektedir.

Tablo 2: Cinsiyetin işten ayrılma niyeti üzerindeki etkisini belirlemeye yönelik t testi

\begin{tabular}{cccccc}
\hline \hline CINSIYET & $\mathbf{N}$ & $\mathbf{X}$ & SS & $\mathbf{t}$ & $\mathbf{P}$ \\
\hline Kadın & 46 & 3,4094 & 0,767 & & \multirow{2}{*}{0,346} \\
\hline Erkek & 74 & 3,4572 & 0,714 & & 0,730 \\
\hline \hline
\end{tabular}

* Anlam düzeyi $\mathrm{p}<0,05$

İşten ayrılma niyeti üzerindeki cinsiyet faktörünün etkisini tespit etmek amacıyla yapılan $\mathrm{t}$ testi sonucunda 0,730 olarak ortaya çıkan P değeri değerlendirildiğinde $(\mathrm{p}<0,05)$ anlamlı bulunmamıştır. T testi sonucuna ve cinsiyet faktörlerinin standart sapmalarındaki yakınlığa bakılarak, cinsiyetin işten ayrılma niyeti üzerinde anlamlı bir etkisi olduğu saptanmamıştır. Bu nedenle turizm sektöründe işten ayrılma niyetinde cinsiyet faktörünün etkisi bulunmamaktadır.

Tablo 3: İ̧̧-aile çatışması ile işten ayrılma niyeti arasındaki ilişkiye yönelik korelâsyon analizi

\begin{tabular}{lccc}
\hline \multicolumn{1}{c}{ DEĞİŞKENLER } & $\boldsymbol{X}$ & ss & \\
\hline İş-Aile Çatışması & 3,1096 & 0,540 & \\
\hline İşten Ayrılma Niyeti & 3,4389 & 0,732 & $0,329^{*}$ \\
\hline \hline
\end{tabular}

* Anlam düzeyi $\mathrm{p}<0,01$

Yapılan korelasyon analizi sonucunda, iş-aile çatışması ile işten ayrılma niyeti arasında orta seviyede, anlamlı ve pozitif yönlü bir ilişki tespit edilmiştir. Bu nedenle çalışanların iş-aile çatışması arttıkça, işten ayrılma niyetlerinin de aynı paralellikte arttığından bahsedilebilir. 
Tablo 4: Hipotez testine ilişkiye yönelik regresyon analizi

Bağımlı Değişken: İşten Ayrılma Niyeti

\begin{tabular}{lcccccccc}
\hline $\begin{array}{l}\text { Bağımsız } \\
\text { Değişken }\end{array}$ & $\boldsymbol{\beta}$ & $\mathbf{R}$ & $\mathbf{R}^{2}$ & $\begin{array}{c}\text { Düzeltilmi } \\
\mathbf{R}^{2}\end{array}$ & $\begin{array}{c}\text { Tahminin } \\
\text { Standart Ha- } \\
\text { tas1 }\end{array}$ & $\mathbf{t}$ & $\mathbf{F}$ & Sig. \\
\hline $\begin{array}{l}\text { İş-Aile } \\
\text { Çatışması }\end{array}$ & 0,243 & 0,329 & 0,108 & 0,100 & 0,51263 & 10,088 & 14,292 & 0,000 \\
\hline \hline
\end{tabular}

Korelâsyon analizi sonucunu desteklemek ve araştırmanın hipotezi olarak belirlenen "İş-aile çatışması ile işten ayrılma niyeti arasında pozitif yönlü bir ilişki vardır." önermesini test etmek amacıyla basit regresyon analizi yapılmıştır. Yapılan analizi sonucunda; $R^{2}$ değeri, 0,100 olarak bulunmuş$\operatorname{tur}\left(R^{2}=0,100 ; F=14,292 ; p>0.01\right)$. Bu duruma göre iş-aile çatışması, işten ayrılma niyeti üzerinde \%10'luk pozitif yönlü bir etkiye sahiptir. Dolay1sıyla araştırmanın hipotezi kabul edilmiştir.

\section{Sonuç}

Bu çalışmada, bir hizmet kolu olan turizm sektörü çalışanlarının yaşadıkları iş-aile çatışmaları ile işten ayrılma niyeti arasındaki ilişkinin tespit edilmesi amaçlanmıştır. Bu amaç doğrultusunda çalışma Balıkesir ili Edremit İlçesinde bulunan konaklama işletmeleri ve seyahat acentelerinde görev yapan 120 personel üzerinde gerçekleştirilmiştir.

$\mathrm{Bu}$ çalışmanın çeşitli kısıtları bulunmaktadır. Öncelikli olarak hizmet sektöründe faaliyet gösteren değişik birçok faaliyet alanı bulunmasına rağmen, araştırma sadece turizm sektörü açısından değerlendirilmiştir. Turizm sektöründe mevsimsellik, yoğun mesai koşulları ve diğer faktörler göz önünde bulundurulduğunda yapılan çalışmanın sonuçları diğer hizmet sektörleri açısından değişiklik gösterebilecektir. Bu nedenle söz konusu araştırmanın tüm hizmet kollarını kapsayacak şekilde yeniden yapılmasında literatüre katkısı açısından yarar vardır. Ayrıca anket sorularına verilecek cevapların gerçeğe en yakın cevaplanması için personel devamlılığ miştir.

Elde edilen araştırma verilerine göre yapılan korelasyon ve regresyon analizlerinde, iş-aile çatışması ile işten ayrılma niyeti arasında anlamlı, düşük düzeyde ve pozitif yönlü (\%10 etki dereceli) bir ilişki olduğu tespit edilmiştir. Çalışanların yaşamış oldukları iş-aile çatışmalarının derecesi 
arttıkça aynı paralellikte işten ayrılma niyeti de arttığı anlaşılmaktadır. işaile çatışmasından kadınların daha çok etkilendiği yönündeki birçok araştırma sonucuna rağmen iş-aile çatışmasının işten ayrılma niyeti üzerinde cinsiyetin etkisi yapılan $\mathrm{t}$ testinde tespit edilmemiştir. Bu durumun nedenlerinden birisi olarak turizm sezonu dışında iş bulma olanaklarının kısıtlı olması gösterilebilir.

Çalışanların ailelerine karşı olan sorumluluklarından doğan rollerin beraberinde getireceği sorunlar, doğal olarak işyerine ve işlerine yansıyacak olup, iş-aile çatışması yaşanacaktır. Yaşanan çatışmalar çalışan ve işletme açısından birçok olumsuz durum ortaya çıkartırken bu olumsuzluklar işten ayrılma niyeti olarak karşımıza çıkmaktadır.

Bu nedenle turizm sektöründeki iş-aile çatışmalarının, işten ayrılma niyeti üzerindeki etkisini en aza indirmek için;

- Ülkemizdeki turizm sektörü çalışanlarının, gelişmiş ülkelerde uygulanan uluslararası çalışma koşullarına kavuşmasının sağlanması

- Turizm sektöründe mevsimsel çalışma koşullarının, çalışan üzerindeki bakışı göz önüne alındığında, mevsimsellik faktörünü azaltacak çalışmaların ilgili paydaşlarca yapılması,

- Özellikle konaklama işletmelerindeki yoğun çalışma koşullarının iyileştirilmesi için gerekli düzenlemelerin yapılması,

- Örgüt kültürünü benimseme ve kişisel gelişim için personel eğitimine daha fazla önem verilmesi,

- İşletmelerce çalışanların ailelerine yönelik (kreş imkânı, tesis imkânlarından ücretsiz yararlanma v.b. gibi) sosyal olarak bütünleşmeyi sağlayacak imkânların sunulması faydalı olacaktır. 


\title{
Extended Abstract
}

\section{A Research in Tourism Sector Towards Determining the Influence of the Conflict of Work-Family on the Intention of Quitting the Job: Edremit Bay Example}

\author{
* \\ Ergün Kara \\ Osmaniye Korkut Ata University
}

People naturally spend a great deal of their lives balancing their jobs and their families. However, nowadays, as individuals begin to work more and more towards their increasing needs and desires, there is an imbalance between the roles that are undertaken for work and family. The work-family conflicts that have arisen due to these floods between the roles are affecting the employees from various issues and they are about the intention of the employee to leave the work. The work-family conflicts experienced by employees in the survey were examined and the impact on the intention to leave work was examined and it was found that there was a positive relationship between work-family conflict and intent to leave work in terms of tourism sector.

It is crucial that people establish a healthy, productive and effective balance between work and family life not only for themselves but also for the future of the family and the social structure of society. Factors such as structure of organization, organizational culture, career goal, field of activity, married or single, number of children, partner's work, etc. have a direct impact on work-family conflict. Conflicts can lead to serious problems in the family life of the employees, as well as negative effects on the employee's job satisfaction, organizational loyalty, performance and creativity. Therefore, one of the issues that directly affects the work-family conflict is the intention of the employee to leave the job.

The work-family conflict with the study has been put forward together with the reasons for the intention to leave the work and the results have been examined. In Edremit Gulf, which is determined as an example mass in the survey, it has been tried to determine to what extent the work-family conflicts 
affect the intention to leave the work on the personnel working in the tourism sector. In the first and second part of the study, the work family conflict and the intention to leave the work were conceptually examined. In the third part, the hypothesis was examined by examining the relationship between the two expressions and the resulting data were evaluated at the end of the study.

In the study, it was aimed to determine the dimension and direction of the relationship between work-family conflict and intention to leave work, and to suggest suggestions for solution. The hypothesis of the research is determined as follows, in the direction of the aim of the study and the results of the literature search.

Hypothesis-1: There is a positive relationship between work-family conflict and intention to leave work.

Questionnaire was used as the data collection method for the research. The study was conducted as a universe of four and five-star accommodation enterprises located in the Edremit province of Balıkesir province and 200 personnel working in the travel agency. Personnel who are continuously employed in the winter season have been preferred for the research because the questionnaire study to be carried out on the seasonal personnel will not give a healthy result. This affected the rate of participation in the survey and 120 questionnaires with healthy responses among the returned surveys were subject to the survey.

In the first part of the prepared questionnaire, the demographic characteristics of the participant were examined by using Carlson et al. (2000), reliability coefficient of which was 0.92 and reliability scores of 0.93 for Reychav and Weisberg (2009) were used for expressions 14-19 and for work-family conflict developed intent to leave work scale. In the questionnaire, 5 likert type scale was used $(1=$ Absolutely not, $2=$ Not agreeable, $3=$ Unstable, $4=$ Agree, $5=$ Absolutely agree).

When the value of $\mathrm{P}$ appeared 0,730 as a result of the $t$ test to determine the effect of gender factor on the intention to leave the intestine, it was not found meaningful $(p<0,05)$. Given the $T$ test result and the proximity of the standard deviations of gender factors, gender was not found to have a significant effect on the intention to leave the work. For this reason, there is no gender factor in the intention to leave work in the tourism sector.

As a result of the correlation analysis, a significant, positive and positive relationship was found between the work-family conflict and the intention to 
leave work. For this reason, as the work-family conflict increases, the intention to leave the work also increases in parallel.

A simple regression analysis was conducted to test the suggestion of supporting the result of the correlation analysis and the hypothesis of the research that "there is a positive relationship between the work-family conflict and the intention to leave work". As a result of the analysis made; The R2 value was found to be 0.1100 ( $R 2=0.10, F=14.292$, $p \& g t ; 0.01)$. According to this situation, the work-family conflict has a $10 \%$ positive effect on the intention to leave work. Therefore, the research hypothesis has been accepted.

In this study, it was aimed to determine the relationship between the work-family conflicts experienced by tourism sector employees who are a service line and their intention to leave work. In line with this aim, the study was carried out on 120 staff working in the accommodation operations and travel agencies located in the Edremit province of Balıkesir province.

This study has several limitations. Although there are many different fields of activity primarily operating in the service sector, the research has only been evaluated in terms of the tourism sector. Given seasonality, intense working conditions and other factors in the tourism sector, the results of the study may vary in terms of other service sectors. For this reason, it is beneficial for the literature to contribute to the reconstruction of the research so as to cover all service branches. Furthermore, the selection of the winter season, which is personnel continuity, has affected the level of participation in the survey for the closest answer to the question of the answers to the questionnaire.

In the correlation and regression analyzes made according to the obtained research data, it was determined that there is a meaningful, low level and positive (10\% effect level) relationship between work-family conflict and intention to leave work. It is understood that as the number of work-family conflicts experienced by employees increases, the likelihood of leaving the work increases in parallel. family conflict was not detected in the t test on which the gender effect was made on the intention to leave the work despite the fact that the work-family conflict was more influenced by women. One of the reasons for this is the limited availability of jobs outside the tourist season.

Problems that arise from the responsibilities of the employees' responsibilities towards their families will naturally be reflected in the workplace and business, and there will be a work-family conflict. When the conflicts that are happening cause a lot of negative situations in terms of employee and business, these negativities are antagonistic as intention to leave the work. 
For this reason, the following factors are important to minimize the effect of work-family conflicts in the tourism sector on the intention to leave work:

$\checkmark$ Ensuring that the tourism sector employees in our country meet international working conditions applied in the developed countries

$\checkmark$ When seasonal working conditions in the tourism sector are taken into account and the employees' perceptions are taken into consideration, studies to reduce the seasonality factor should be carried out by the relevant stakeholders,

$\checkmark$ Making the necessary arrangements in order to improve the working conditions especially in accommodation enterprises,

$\checkmark$ Greater emphasis on staff training for organizational culture adoption and personal development,

$\checkmark$ It will be useful to provide opportunities for socio-integration towards the families of the employees of the enterprise (such as the provision of nursery facilities, free use of facilities, etc.).

\section{Kaynakça/References}

Adams. G. A. King. L. A. ve Daniel. W. (1996). Relation ships Job and Family Involvement, Family Social supportand Work-Family Conflict With Joband Life Satisfaction. Journal of Applied Pyschology 81. 403-411.

Aslan. Z. ve Etyemez. S. (2015). İşgörenlerin Tükenmişlik Düzeylerinin İşten Ayrılma Niyeti Üzerine Etkisi: Hatay'daki Otel İşletmelerinde Bir Araştırma. İşletme Araştirmalarn Dergisi. 7/3: 482-507.

Babajide. Elsie. O. ve Olabisi. O. (2010). The Influence of Perfornal Factors on Workers' Turn over Intention in Work Organizations in South-West Nigeria. Journal of Diversity Management. 5/4.

Barrick. M. R. Stewart. G. L. ve Piotrowski. M. (2002). Personality And Job Performance: Test Of The Mediating Effects Of Motivation Among Sales Representatives. Journal of Applied Psychology. 87/1: 1-9.

Carlson. D. S. Kacmar. K. M. ve Williams. L. J. (2000). Construction and Initial Validation of a Multi dimensional Measure of Work-Family Conflict. Journal of Vocational Behavior. 56. 249-276.

Chusmir. L. H. ve Parker. B. (2001). Success Strivings and Their Relationship to Affective Work Behaviours: GenderDifferences. TheJournal of Social Psychology 132: 8799.

Clark. S. C. (2000). Work/Family border theory: A new theory of work/family balance. Human Relations. 53 (6): 747-770. 
C,arıkç. I. H. ve C,̣elikkol. O. (2009). Iss,-Aile C,atıssmasının Orguitsel Baglılık ve Isșten Ayrılma Niyetine Etkisi. Suleyman Demirel Universitesi. Sosyal Bilimler EnstitüsüDergisi. (9): 153-170.

Doğrul. B. Ş. ve Tekeli. S. (2010). İş-Yaşam dengesinin sağlanmasında esnek çalışma. Sosyal ve Beşeri Bilimler Dergisi. 2(2): 11-16.

Doruk Ç N (2009) Organizasyonlarda is-aile ve aile is çatışmalarının çalışanların is ve yasam tatminleri üzerindeki etkisi. Erciyes Üniversitesi iktisadi ve İdari Bilimler Fakültesi Dergisi (33): 69-99.

Efeoğlu. İ. (2006). İş-Aile Yaşam Çatışmasının İş Stresi, İş Doyumu ve Örgütsel Bağhllık Üzerindeki Etkileri: İlaç Sektöründe Bir Araştırma. Doktora Tezi. Çukurova Üniversitesi. Sosyal Bilimler Enstitüsü. İşletme Anabilim Dalı. Adana.

Frone. M. R. ve Rice. R. W. (1987). Work- Family Conflict: Theeffect of job and family involvement. Journal of Occupational Behavior. 8(1): 45-53.

Frone. M. R. Yardley. J. K. ve Markel. K. S. (1997). Developing andTesting an Integrative Model of the Work-Family Interface. Journal of Vocational Behavior. 50. 145-167.

Greenhaus. J. H. ve Beutell. N. J. (1985). Sources of conflict between work and family roles. Academy of Management Review. 10(1): 76-88

Goldberg. L. R. (1990). An Alternative "Description Of Personality": The Big-Five Factor Structure. Journal of Personality and Social Psychology. 59. 1216-1229.

Küçükusta. D. (2007). Konaklama işletmelerinde iş-yaşam dengesi sorunları ve çözüme yönelik yaklaşımlar. Dokuz Eylül Üniversitesi. Sosyal Bilimler Enstitüsü Dergisi. 9(3): 243- 264

Kossek. E. ve E. Özeki C. (1998). Work-FamilyConflict, Policies, and Job-Life Satisfaction Relationship: A Review and Directions for Organizational Behavior- Human Resources Research. Journal of Applied Psychology. 83(2): 139-149

Lambert. E. G. Hogan. N. L. ve Barton. S. M. (2001). The impact of job satisfaction on turn over intent: a test of a structural measurement model using a national sample of workers. The Social Science Journal. 38(2): 233-250.

Noor. S. ve Nazia. M. (2008). Examining The Relationship BetweenWork Life Conflict, Stress and Turnover Intentions Among Marketing Executives in Pakistan. International. Journal of Business and Management. November. 3/11.

Organ. D. W. ve Lingl. A. (1995). Personality, Satisfaction, and Organizational Citizenship Behaviors. The Journal of Social Psychology. 135(3): 339-350.

Örücü. E. ve Özafşarlığlu. S. (2013). Örgütsel adaletin çalışanların işten ayrılma niyetine etkisi: Güney Afrika cumhuriyetinde bir uygulama. Mustafa Kemal Üniversitesi. Sosyal Bilimler Enstitüsü Dergisi. 10 (23): 335-358.

Powell G. N. ve GreenhausJ. H. (2006). WhenWork and Family Are Allies: A Theory Of Work-Family. Enrichment Academy Of Management Review. Vol. 31/1. 72-92.

Reychav. I.ve Weisberg. J. (2009). Going beyond technology: Knowledge sharing as a tool foren hancing customer- orientedattitudes. International Journal of Information Management. 29(5): 353-361. 
Şahin. F. (2011). Lider-Üye Etkileşimi ile İşten Ayrılma Niyeti Arasındaki İlişki Üzerinde Cinsiyetin Etkisi. Ege Akademik Bakış. Nisan.11/2.

Taslak. S. (2007). İş- Aile çatışmalarının bireysel ve örgütsel sonuçları üzerine uygulamalı bir araştırma. Yönetim dergisi. 18(58): 67-73.

Yenihan. B. Öner. M. ve Çiftyıldız. K. (2014). İş Stresi ve İşten Ayrılma Niyeti Arasındaki İlişki: Otomotiv İşletmesinde Bir Araştırma. Çalı̧ma İlişkileri Dergisi. 5(1): 38-49.

Zedeck. S. ve Mosier. K. L. (1990). Work in the family and employing organization. American Psychologist. (45): 240-251.

Zimmerman. R. D. (2008). Understanding the Impact of Personality Traits on Individuals'Turnover Decisions: A Meta-Analytic Path Model. Personnel Psychology. 61. 309-348.

Dr. Öğr. Üyesi Ergün KARA: 2004 yılında Erciyes Üniversitesi İktisadi ve İdari Bilimler Fakültesi Turizm ve Otel İşletmeciliği bölümünden mezun oldu. 2012 yılında Mersin Üniversitesi Sosyal Bilimler Enstitüsü İşletme Anabilim Dalı'nda Yüksek Lisans eğitimini, 2017 yılında ise Osmaniye Korkut Ata Üniversitesi Sosyal Bilimler Enstitüsü İşletme Anabilim Dalı'nda Doktorasını tamamladı. Kara, Halen Osmaniye Korkut Ata Üniversitesi İ.İ.B.F. İşletme Bölümünde Dr. Öğretim Üyesi olarak görev yapmaktadır. Araştırma alanları Yönetim ve Organizasyon, Stratejik Yönetim, Stratejik Yönetim Uygulamaları, Çevreye Duyarlı İşletmecilik, İşletme Bilimine Giriş, Uluslararası İşletmecilik, İnsan Kaynakları Yönetimi gibi konuları kapsamaktadır.

Assist. Prof. Dr. Ergün KARA, He graduated from Erciyes University, Faculty of Economics and Administrative Sciences, Department of Tourism and Hotel Management in 2004. He completed his master's degree in Business Administration Department of Mersin University Social Sciences Institute in 2012 and his PhD in Osmaniye Korkut Ata University Social Sciences Institute Business Administration Department in 2017. Kara is currently working as an instructor at Osmaniye Korkut Ata University Faculty of Economics and Administrative Sciences Department of Business Administration. His research interests include Management and Organization, Strategic Management, Strategic Management Practices, Environmentally Responsible Business, Introduction to Business Science, International Business, Human Resources Management.

E-Mail: erguncankara1@hotmail.com

\section{Kaynakça Bilgisi / Citation Information}

Kara, E. (2018). İş-Aile Çatışmasının İşten Ayrılma Niyeti Üzerine Etkisini Belirlemeye Yönelik Turizm Sektöründe Bir Araştırma: Edremit Körfezi Örneği. IDEALKENT - Kent Araştırmaları Dergisi, 24, 733-750. 